UDC 37:1/14:316

Hasmik SARGSYAN

\title{
THE FACTORS OF EFFICIENCY OF SOCIO-ECONOMIC MANAGEMENT OF HIGHER EDUCATION
}

\begin{abstract}
The sphere of education is in the center of attention of modern scientific research and political observations. The list of developed countries of the world has always been leading countries that are able to create a highly efficient and up-to-date and a flexible educational system. Practically all countries, which show a rapid economic growth, the development of education is one of the priorities of the state policy. In the context of modern financial constraints, it is necessary to effectively use the existing financial potential. In this regard, one of the most important components of public administration is budget management directed to the development of the education sector.

In this research are presented some issues of effective management of higher education system and is analyzed the international experience in this field. Also the peculiarities of Armenian Higher Education sector are given from the point of view of state policy.
\end{abstract}

Keywords: efficiency of education, factors of efficiency, financing model, social-economic evaluation, efficiency mechanism, personalized approach.

The concept of efficiency is about the relationship between inputs and outputs in a production process. When the production process is characterized by multiple inputs and multiple outputs, like the education sector, a situation can be defined as "efficient" when it is not possible to produce more of some outputs without a reduction in the production of the other outputs. A different allocation of the inputs may yield more of some outputs but will also lead to a lower production of some of the other outputs. A situation can be defined as inefficient when, using the same amount of inputs, it is possible to produce more of some outputs without reducing the production of other outputs. Hence, the concept of efficiency is about the optimal use of resources (see Dinand, 2012).

The analyses of international experience of resources usage in the field of education shows that the system of financing based on the number of students has to entertain with some factors to assess the efficiency of the process.

These three factors are described to assess the efficiency of financial system in the field of education:

1. Social-economic evaluation of the educational environment, which starts with control of institutions and ends in assessment of uniqueness and prosperity of educational organization. This factor has also 
been called "the assessment of environment changes".

2. Monitoring of efficiency of system realization. This factor includes estimation of the dependence between cost estimate assessment and the change in the use of resources and the quality of educational services. The term "monitoring of efficiency mechanisms" is also used for this factor.

3. Evaluation of system's implementation mechanisms, with broad awareness of the expected innovations for all participants (from the assessment of the required level of preparedness and learning to public and professional opinions). Another term for this factor is "analyses of promotion mechanisms".

The analysis of the criteria used by the responsible authorities for allocating school resources, although limited, still provides some interesting findings. In many countries, it is very common for education authorities at top and intermediate levels to use input-based variables for establishing the level of resources to be allocated for staffing. In some countries, education authorities use a limited number of variables related to the number of existing staff or pupils, usually weighted by the level of education or school year. $^{2}$

1 For the details see Reforma byudvetnoj politiki $v$ obrazovanii (The Reform of the Budgetary Policy in Education, in Russian) (2016, June). Bulletin on Education No 08.

2 See European Commission/EACEA/Eurydice, 2014. Financing Schools in Europe: Mechanisms, Methods and Criteria in Public Funding. Eurydice Report. Luxembourg: Publications Office of the European Union.
A great attention toward the US education financing system is largely due to not only very large expenses, but also with the success of the financing model based on the number of students.

California, as one of the largest states in the United States, has not only a large number of students in public schools $(13 \%$ of all country's state school students), but also has the highest rate of student per teacher in the country (student-teacher ratio 23.7/1, while the average of the country is $16 / 1$ ).

In February, 2016 based on the effectiveness analysis of the California State Educational System, amendments were made to the "20162017 California budgets". Of the state's state budget, 5 out of every $10 \$$ state budget goes to education. 2016-2017 The total expenditure is \$ 167.6 billion, most of which are related to education, healthcare, and social services.

The main activities of educational organizations are regulated by the federal law on education and the law of the state of education. The federal law stipulates requirements for local institutions of education to implement the educational criteria, the quality of educational services and the quality of education (learners' educational achievements).

In its turn, federal legislation stipulates conditions for obtaining federal funding under the basic requirements for school: special education services, annual testing according to individual subjects and educational levels.

The federal government also finances various types of programs that have specific requirements. For example, if the school county receives some of the funds from the federal budget, it should show that these funds are used to provide additional services to insecure students. 
At present, there is a standardized model of funding based on a personalized approach and recording of "local" peculiarities. The implementation of this model is carried out within the framework of local financial management and is based on the three basic target indicators of the standard financing model (LCFF).

1. Contributions based on 4 groups of classes. Different indicators and various levels of resource support are used for pre-school, elementary, secondary and general education. For example, the basic input for higher school increases due to higher costs of providing technical education. An exception is a group of 1-3 grades, where the indicator is higher than the contribution for grades $4-8$, as the number of pupils in elementary school is lower, which is important in the number of normative pupils.

2. A form of additional financing. In the framework of a personal oriented approach, the registration of students' needs and requirements, the level of social-economic provision of the family, requires a usage of a certain standard size of additional funding. For example, additional funding norms are used for English researchers, vulnerable families, dependent children, and low-income families.

3. Rising the standard of financing. The use of the increasing funding standard is determined by the number of vulnerable, socioeconomically insecure students. ${ }^{3}$

Across Europe, the most common way for central/top level ministries to establish the

3 For the details see Reforma byudvetnoj politiki $v$ obrazovanii (The Reform of the Budgetary Policy in Education, in Russian) (2016, June). Bulletin on Education No 08. level of resources for teaching staff is to use a funding formula.

The 28 education systems using this method can be divided into two broad categories: first, those systems where funds for teaching staff are part of a lump sum or block grant awarded either to school level authorities or to intermediate authorities; second, those systems where ministries award either a grant earmarked for teaching staff costs to the relevant bodies or authorities, or where ministries pay teachers directly.

Countries in the north of Europe usually belong to the first category. The number in each category is the same. In Poland, Finland, Sweden and the United Kingdom (Wales and Scotland) and Norway, local authorities, which have significant autonomy in the management of public services - including education, are awarded a lump sum on the basis of a funding formula. This lump sum, which may be a small amount in some countries, is used for buying or allocating the resources needed for the running of public services under their remit. ${ }^{4}$

The total undergraduate educational expenses associated with attending the University will be considered in assessing need. These expenses will include direct educational costs for a modest allowance for living, transportation, and miscellaneous items. Differences in the cost of living and the residence patterns of students at the campuses will be recognized. A standard methodology will be used by the campuses for determining the undergraduate

4 See European Commission/EACEA/Eurydice, 2014. Financing Schools in Europe: Mechanisms, Methods and Criteria in Public Funding. Eurydice Report. Luxembourg: Publications Office of the European Union. 
student expense budgets that are used in the Education Financing Model:

- in providing cost information to students and the public;

- in packaging financial aid to students;

- in the implementation of the Education Financing Model.

The Standard Methodology has two components.

1. The allowable expenses to be included under each budget category (fees, books, housing, food, transportation and personal). Campuses may include, at their option, additional types of expenses as adjustments to the budgets on an individual case basis.

2 . The calculation of the amount of the allowable expense under each budget category. Actual allowable expenditures for each nonfee budget category will be determined from average student expenditures as measured by the Cost of Attendance Survey (COAS), which was first conducted in 1997. There are two exceptions to the use of actual survey data for determining allowable expenses. First, for students living on-campus, actual on-campus housing costs will be used instead of selfreported on-campus housing costs. Second, a health care component will be included in the student expense budget (see Education Financing Model Implementing Guidelines, 1998).

The long-term development strategy of the Republic of Armenia, one of the key priorities of the Sustainable Development Program, is the reform and development of the higher education sector. These goals today are more actual as Armenia is accelerating its steps towards joining the European Higher Education Area in line with the Bologna process. A number of important achievements have been recorded in this direction, including the introduction of bachelor and master programs, the introduction of the European Credit Transfer System, and so on. At the same time, the existing principles and mechanisms of higher education financing are not in line with the Bologna Process and do not support the expansion and implementation of reforms in this area.

Over the past decade, a number of events have been undertaken in Armenia to transform the higher education sector, but there are still unresolved issues and complications that distract attention from the quality of teaching and research activities conducted by the sector and slow down the process of effective implementation of further reforms in the sector. These are the remaining issues.

1. Funding is based on receipts. While the Armenian government has made a transition to the system of student benefits from the government system, the funding mechanism remains largely based on receipts rather than results. In other words, funding is based on the number of students in different courses, but not the number of graduates who have a successful and necessary knowledge base.

2. A lack of stimulus and accountability. According to universities, the allocation of «state-funded» places is based primarily on actual data, but is not linked to the quality or effectiveness of the universities. Additionally, very little or no general information is collected or published on the activities of HEIs, such as leaving students, duration of training, effectiveness, and more. As a result, universities currently have no definite incentives to satisfy their performance.

3. Hyper specialization. Within the framework of the existing system, the Govern- 
ment of the Republic of Armenia still defines student benefits in more than 200 separate specializations, and one student scholarship allowance ranges from 2 to 60 in one speciality. Such a high level of specialization limits mobility of students and the flexibility of universities.

4. Market Demand Compliance. The choice and demand of students play a minor role in the current system of higher education financing. There is a significant unsatisfactory demand. Specialization quotas are problematic, given the high degree of government regulation.

5. Student/Staff low coefficient. The student/lecturer coefficient in the Armenian average is only 9.4 , while the lecturer / administrative staff coefficient is 1 . In OECD countries, the average student / teacher ratio is 15 . Such inefficiency is largely the legacy of the Soviet Union when a large number of administrative workers were employed than needed.

6. Excessive attention to social issues. A significant proportion of higher education budgets are allocated for social, not educational purposes. Students' scholarships do not affect either accessibility or quality of life, though significantly increases government spending, providing financial support to students. ${ }^{5}$

According to international experience, a well-functioning higher education sector should have the following characteristics:

5 See Hayastani Hanrapetut'yan bard'raguyn krt'ut'yan finansavorman r'azmavarut'yun. (Higher Education Financing Strategy of the Republic of Armenia, in Armenian). Annex 1 Government of Armenia 2011, June 30 session No 25.
- The government should determine the amount of public funding for various functions, including institutional support, student financial allowance and research funding.

- The intermediary bodies should be primarily responsible for determining how public funds are allocated to universities, how quality is assured and how the student financial allowance is allocated.

- Universities should be primarily responsible for the development of curricula and other academic issues, as well as for maintaining and improving the quality of the institution.

For a good instituional governance system universities should have autonomy in spending public funds along with taking government action against abuses.

Universities should ensure accountability by obtaining state funding for the next year based on the results of the current year expenditures. The government or universities should define the rent within the family financial capacity and the private value of education.

Any realistic assessment of Armenia's higher education should include concerns about how the existing governance system contributes to addressing the challenges facing the sector. Any modification of the financing system should provide for the redeployment of the management system. Without such a change, financial transformation changes will probably not take place because there will be no prerequisite for their successful implementation.

There are a number of management-related issues that need to be considered as an integral part of the development strategy of a financial reform. These are: 
- a large number of HEIs,

- Traditional separation of teaching and research activities;

- Inadequate supervision of university tuition fees and asset management over the year end;

- Absence of full integration in the Bologna process,

- The need to strengthen quality assurance processes.

Large number of HEIs. There are 77 state and private universities and more than 100 state and private colleges in Armenia. For any country like Armenia, this is an extremely large number of institutions. The average number of students enrolled in state HEIs is 35007 , and in private - up to 1000 , in colleges - less. This means that most Armenian HEIs are unable to provide an effective outcome of economic activity as institutions are too small. This also means that students' choices are extremely limited, as most universities are unable to offer their students a full course of training. It is important that the financial strategy will address this source of ineffectiveness. ${ }^{6}$

Separation of teaching and research work. Armenia is still applying the Soviet model, where different teaching and research activities are being separated, including a large part of research activities carried out in institutions independent from HEIs. In addition, the teaching staff of the universities does not have or have almost no responsibility for research.

6 See Higher Education Policy Center (CHEPS) report (2008). Formation of Funding Principles and Alternative Financing Mechanisms Search for Three-Level Education System in Armenia.
It is stunning that higher education and research in Armenia are periodically discussed as separate events.

The international experience of scientific research in higher education shows that such degree of division has largely reduce the quality of higher education. As with institutional fragmentation, teaching and research work the problem of separation should be resolved within the framework of the strategy of financial transformation.

Lack of effective control by the government. In the case of Armenia, state HEIs are principally given a high degree of autonomy but not in all aspects of their activity. The Law on Higher Education provides universities with the status of independent institutions as a state non-commercial organization.

From the point of view of funding, the law provides for each State University independence "at its discretion to define the staff list of all categories, to select and distribute staff, including academic and pedagogical staff, rules for replenishment of vacancies, as well as positions of chairs and faculties" (Article 6(3)). The law also allows universities to employ academic staff on a competitive basis for a five-year term and determine the staff remuneration, which should give them significant flexibility in terms of demanddriven employment.

However, the high level of institutional autonomy in some respects has not led to improved governance. There is no effective system that would limit the tuition fees of Armenian universities, and the fact that the government finances higher education with a smaller amount of foreign experience, even worse by this predicament. Similarly, the fact that most 
universities have generated a surplus is another indicator of non-operating governance.

Integration in the Bologna Process. Governance issues in Armenia should also be considered in the context of the Bologna Process, a comprehensive system of European Higher Education Reforms that began in 1999. The "State Expenditure Survey", published by the World Bank in 2008, states that "Armenia has made progress in some aspects of the Bologna process, but still reduces to quality assurance and qualifications". This conclusion is still actual for nowadays. It demonstrates the need for quality assurance as well as the need to improve the management system.

It is clear that Armenia has made some progress towards bringing the diploma and qualification system in line with the Pannier process, but progress is mainly limited to technical aspects, such as the diploma system. $^{7}$

Clearly, the measures taken so far have not been enough for the "spirit" of the Bologna process to truly apply "student-centered, learner-centered approaches". Diplomas are still characterized by the content of the program and / or the time required to obtain a diploma and not with the education results. They continue to dominate practice and outdated teaching methods, and the constant assessment has simply been added to the system of traditional hard tests at the end of the year rather than replacing them. If the educationbased system is maintained, this will probably be controversial with long-term education, as well as with flexibility in education and recognition of previously-recognized education.

\section{REFERENCES}

Dinand, W. (2012). Efficiency in Education. Erasmus School for Education: University of Rotterdam.

Education Financing Model Implementing Guidelines (1998). University of California.

European Commission //EACEA// Eurydice, 2014. Financing Schools in Europe: Mechanisms, Methods and Criteria in Public Funding. Eurydice Report. Luxembourg: Publications Office of the European Union.

Formation of Funding Principles and Alternative Financing Mechanisms Search for Three-Level Education System in Armenia. Higher Education Policy Center (CHEPS) report (2008).

7 See Hamashxarhayin bank "Hayastani krt'ut'yan olorti petakan c'axseri usumnasirut'yun" (World Bank "State Expenditure Study in Armenia", in Armenian) (2008), p. 15. 